\title{
Para-Aminohippurate Sodium Measurement
}

National Cancer Institute

\section{Source}

National Cancer Institute. Para-Aminohippurate Sodium Measurement. NCI Thesaurus.

Code $C 127631$

The determination of the amount of para-aminohippurate sodium present in a sample. 